\title{
Crohn's disease in a developing African mission hospital: a case report
}

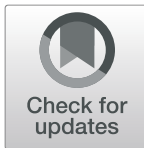

Bamidele Johnson Alegbeleye

\begin{abstract}
Background: A case is reported of innocuous intestinal obstruction requiring surgical intervention that was confirmed to be Crohn's disease histopathologically in a resource-constrained rural mission hospital in Cameroon.

Case presentation: A 70-year man of Kumbo origin from Northwest region of Cameroon with a history of crampy right lower-quadrant abdominal pain, non-bloody, non-mucoid diarrhea alternating with constipation presented to my institution. Abdominal examination of the patient revealed an ill-defined mass in the right iliac fossa and visible peristalsis. An abdominal computed tomographic scan and barium enema study confirmed a complex ascending colonic and cecal tumor. The patient underwent exploratory laparotomy. The intraoperative finding was a huge complex inflammatory mass involving the cecum, terminal ileum, and sigmoid colon. He subsequently had sigmoidectomy with end-to-end sigmoidorectal anastomosis and a cecal resection, and the proximal ascending colon was exteriorized because end mucoid fistula and terminal ileostomy were performed. The histopathological diagnosis confirmed Crohn's disease. The patient subsequently received five courses of adjuvant chemotherapy consisting of azathioprine, methotrexate, mesalamine, and methylprednisolone. He had complete disease remission and subsequently had closure of ileostomy with satisfactory postoperative status. The most recent follow-up abdominal computed tomographic scan and colonoscopy revealed disease-free status. The patient is also currently receiving a maintenance dose of rectal mesalamine and oral omeprazole treatment. He has been followed every 2 months in the surgical outpatient clinic over the last 16 months with satisfactory clinical outcome.

Conclusions: Crohn's disease is uncommon in Africa, and this entity is encountered sparingly. The signs and symptoms of Crohn's disease overlap with many other abdominal disorders, such as tuberculosis, ulcerative colitis, irritable bowel syndrome, and others. Several publications in the literature describe that it is difficult to make an accurate diagnosis of this disease, despite the fact that many diagnostic armamentaria are available to suggest its presence. Most of the patients with Crohn's disease are treated conservatively, and a few may require surgical intervention, especially those presenting with complications such as intestinal obstruction, perforations, and abscess as well as fistula formations, as seen in this index patient. Crohn's disease is considered by many to be a very rare disease in Africa. It is interesting to know that Crohn's disease, which affects mainly young adults, may debut at any age. The rarity and clinical curiosity of this entity suggested reporting of my patient's case. Evidence-based up-to-date information on Crohn's disease is also documented.
\end{abstract}

Keywords: Crohn's disease, Autoimmune disorder, Granulomatous colitis, Regional enteritis

(C) The Author(s). 2019 Open Access This article is distributed under the terms of the Creative Commons Attribution 4.0 International License (http://creativecommons.org/licenses/by/4.0/), which permits unrestricted use, distribution, and reproduction in any medium, provided you give appropriate credit to the original author(s) and the source, provide a link to the Creative Commons license, and indicate if changes were made. The Creative Commons Public Domain Dedication waiver (http://creativecommons.org/publicdomain/zero/1.0/) applies to the data made available in this article, unless otherwise stated. 


\section{Introduction}

Crohn's disease (CD), also referred to as regional enteritis, granulomatous enterocolitis, and terminal ileitis, is a chronic relapsing and remitting inflammatory disease of unknown cause that is often multifocal and can affect any portion of the gastrointestinal tract (GIT) [1]. It is generally accepted that the Scottish surgeon Dalziel gave the first account of the disease in 1913 [2]. In the 1960s, Lockhart-Mummery and Morson described the involvement of the large intestine by CD [3], and it was in the 1950s that anal and anorectal CD were described [4]. In time, it became clear that CD can involve any part of the digestive tract and that extraintestinal manifestations can be present, especially in the skin, eyes, and joints [5-9].

Epidemiological studies showed that $C D$ has an incidence of 3 to 20 cases per $100,000[10,11]$. CD is more common in the industrialized world, particularly in North America and Western Europe, though the incidence is rising in Asia and South America [10, 12, 13]. There may be a slightly higher predominance of CD in women, and it is more common in individuals of Ashkenazi Jewish origin than in non-Jews. The exact pathogenesis of CD is unknown, although there are a number of genetic and environmental factors that have been shown to increase the risk of the disease and lead to the aberrant gut immune response characteristic of the disease $[10,12]$.

In a related development, other literature suggested a "north to south gradient" with respect to the incidence of CD. North America (7 to 10.3/100,000 per year), the United Kingdom (8.3 to $9.1 / 100,000$ per year), and Northern Europe (5.8-6.3/100,000 per year) have the highest incidence of $\mathrm{CD}[10,12,13]$. The prevalence of CD also demonstrated a similar pattern, which is reported to be 207/100,000 per year in North America, $156 / 100,000$ per year in the United Kingdom, and 90/ 100,000 per year in Northern Europe [14-20]. However, owing to limited information on inflammatory bowel disease (IBD) in southern countries, this "gradient" is not widely accepted.

Furthermore, there are only a few studies on the incidence and prevalence of CD in Latin America [14, 21]. Although the incidence of CD in South America has been surveyed to be lower than in North America, in the last 50 years, occidental countries have reported a rise in both incidence and prevalence of IBD [14, 21]. Another study mentioned that Puerto Rico has the lowest incidence of IBD within the southern American subregion [14, 22]. Yamamoto-Furusho, in his study of a Mexican population, reported an increasing incidence of ulcerative colitis (UC) from 1987 to 2006, with a 2.6-fold increase from 1997 to 2006, compared with the previous decade. This increasing incidence of UC has been linked to environmental factors and the unique genetic mosaic of the Mexican population, but there is no information regarding $C D$ incidence in Mexico to date [14, 23].

The rarity of $\mathrm{CD}$ and the prevalence of tuberculous enterocolitis in Africa and Asia in general tend to unnecessarily make clinicians hesitant to diagnose a CD both clinically and histologically [9, 24-27]. Its differentiation from UC is always a problem, but the distinction from tuberculosis is rather more difficult in developing countries if the lesion is granulomatous [9, 24-27]. Surgically resected bowel segments again require a close examination using various diagnostic criteria to diagnose or exclude a CD [9, 24-27]. This case of histopathologically confirmed $\mathrm{CD}$ is presented because of the rarity and clinical curiosity of this entity. Evidence-based, up-to-date information on CD is also presented.

\section{Case presentation}

A 70-year-old man of Kumbo origin from the Northwest region of Cameroon was admitted to a rural mission hospital in Cameroon with a history of crampy right lower-quadrant abdominal pain, nonbloody, nonmucoid diarrhea alternating with constipation for the last 5 days. Anorexia and low-grade fever were observed, but no weight loss. Abdominal examination revealed the features of acute intestinal obstruction with an ill-defined mass in the right iliac fossa (RIF) and visible peristalsis. A chest radiograph was essentially normal. An abdominopelvic ultrasound scan showed dilated bowel loops and an RIF mass. An abdominal plain radiograph showed multiple air-fluid levels and dilated bowel loops. An abdominal computed tomographic (CT) scan and barium enema study confirmed a complex ascending colonic and cecal tumor. The patient had a markedly raised white blood cell count of 40,300 cells $/ \mathrm{ml}$. The C-reactive protein was significantly elevated, and results of the tuberculin test and Genexpert test for tuberculosis were both negative. The patient's blood pressure was $129 / 78 \mathrm{mmHg}$, and his pulse rate was 60 beats/min. He also had pyrexia $\left(-37.9^{\circ} \mathrm{C}\right)$. In view of acute intestinal obstruction, exploratory laparotomy was performed after routine investigations. The intraoperative finding was a huge complex inflammatory mass involving the cecum, terminal ileum, and sigmoid colon. The patient subsequently had a sigmoidectomy with end-to-end sigmoidorectal anastomosis and a cecal resection, and the proximal ascending colon was exteriorized because end mucoid fistula and terminal ileostomy were performed. Figure 1 is a postoperative photograph showing the ileostomy and disposable stoma bag. Figure 2 is the immediate postoperative photograph of the resected complex mass involving the cecum, terminal ileum, and sigmoid colon. Histopathological examination of the resected specimen showed macroscopic appearance of a complex large mass (Fig. 3) involving the cecum, sigmoid colon, and terminal ileum, with congested swollen mucosa 


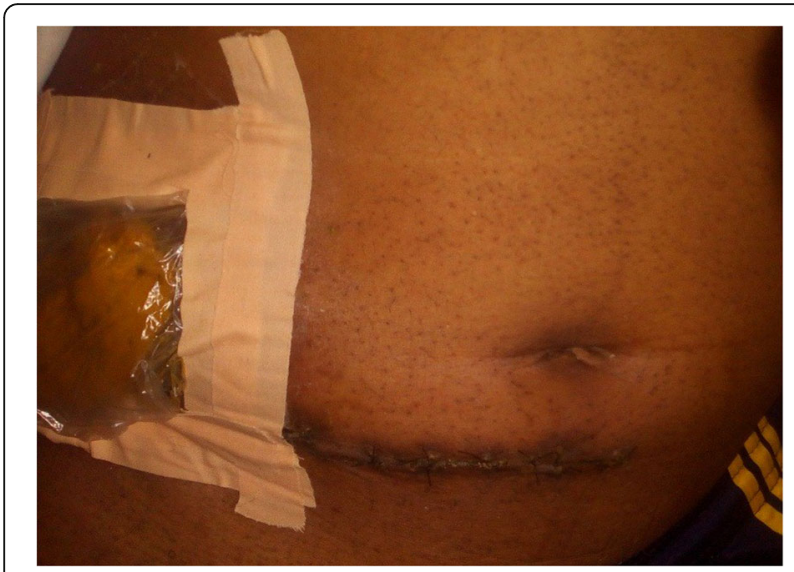

Fig. 1 The index patient

interspersed with diffused, irregular ulcerations with a cobblestone appearance (noncaseating granulomas in all layers of bowel wall from serosa to mucosa). Also, multiple fissures were present, as well as perforation and fistula seen between adjourning bowel loops, but no significant IBD was observed in nonulcerated mucosa. Microscopically, prominent and enlarged lymphatic follicles, proliferation of muscularis mucosa, and formation of fissures extending from mucosa to serosa along with gross edema. Marked infiltrates of inflammatory cells involved all the bowel layers; the details are depicted in Fig. 4. Therefore, histopathological diagnosis of $\mathrm{CD}$ was made. The postoperative period was uneventful. Thereafter, the patient received five courses of adjuvant chemotherapy consisting of azathioprine (AZA), methotrexate (MTX), mesalamine, and methylprednisolone. He had complete disease remission and subsequently underwent closure of

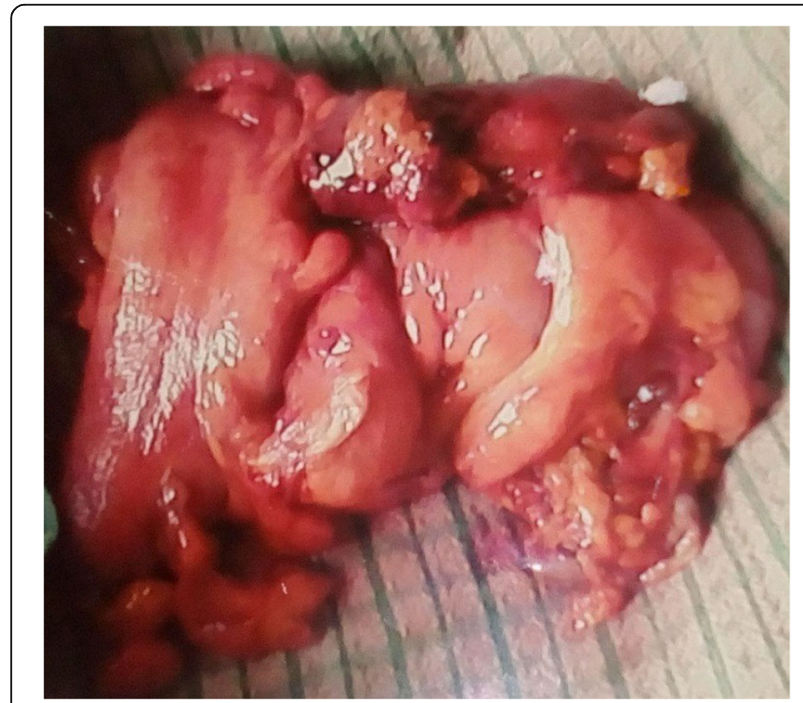

Fig. 2 Post op bowel specimen

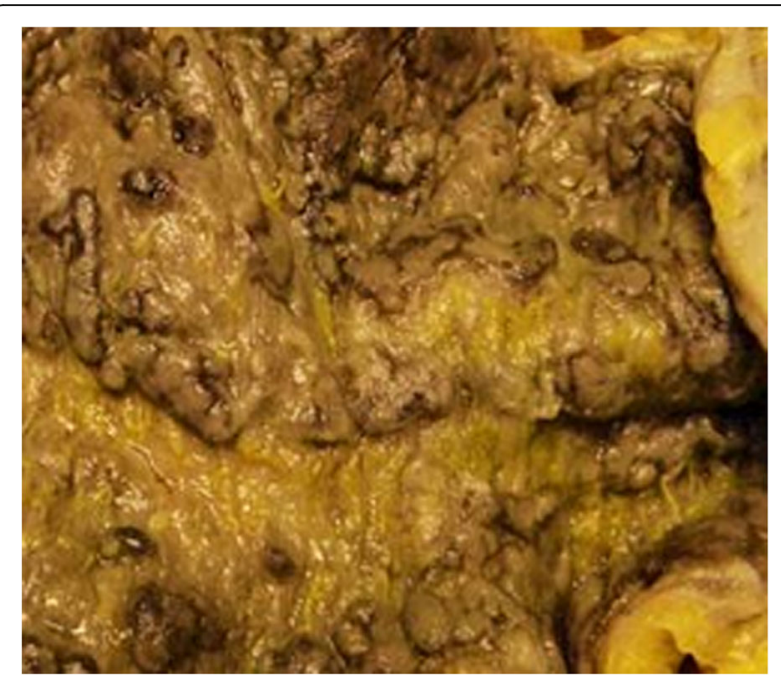

Fig. 3 Colonic Crohn's disease

the ileostomy with satisfactory postoperative status. The most recent follow-up abdominal CT scan and colonoscopy revealed disease-free status. The patient is also currently receiving a maintenance dose of rectal mesalamine and oral omeprazole treatment. He has been followed every 2 months in the surgical outpatient clinic over the last 16 months with a satisfactory clinical outcome.

\section{Discussion}

$\mathrm{CD}$ causes inflammation of the digestive tract. It can affect any area of the GIT from mouth to anus; however, it most commonly affects the ileum [28]. In CD, all layers of the intestine may be involved, and normal healthy bowel can be found between sections of diseased bowel. CD affects men and women equally in all age groups, with a predilection in the second and third decades and familial preponderance in a few [29]. IBD was once considered rare in the developing world; its epidemiology is changing, and the incidence of both $\mathrm{CD}$ and $\mathrm{UC}$ is increasing in the Asia-Pacific region, India,

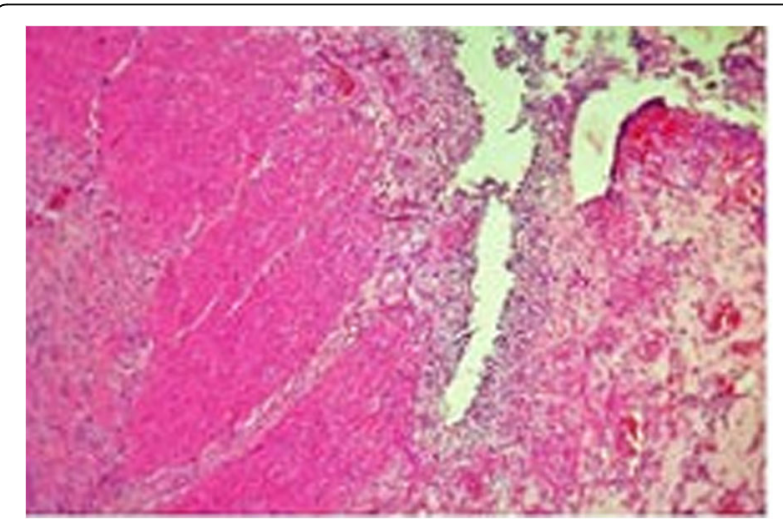

Fig. 4 The histopathology slide 
Eastern Europe, and South Africa [30-33]. There have been very few reported cases of $\mathrm{CD}$ in black African patients in Kenya and South Africa [34]. The symptoms, anatomical distribution, signs, and pathology in black patients in Africa and America are similar to those described in white individuals. The disease is probably underdiagnosed in Africa because of difficulties in distinguishing schistosomiasis and tuberculosis of the bowel [24, 35-37]. The etiology of CD remains incompletely known, although several theories have been issued, such as the involvement of genetic factors, environmental factors (including diet), and infective agents [24-26]. CD is directly correlated with a triad of predisposing factors, including genetic problems, immune system malfunctions, and environmental factors [24-26].

$\mathrm{CD}$ usually presents with abdominal pain especially due to involvement of ileum, blood-stained diarrhea, and anemia. Some patients with CD may have low-grade fever, nausea, and vomiting. Fissures or cracks may be evident, and fistulas and abscesses may form in anal involvement [38]. CD may also present with extraintestinal manifestations such as skin or mouth lesions, pain in the joints, eye irritation, kidney stones, gallstones, and other diseases of the hepatobiliary system [39]. Affected children may have delayed milestones. Patients with severe cases of CD may have most common complications such as intestinal blockage with thickening and fibrosis of the affected segment [40].

The diagnosis of $\mathrm{CD}$ is a clinical one and can be quite difficult, given that the presenting symptoms can be insidious and nonspecific [41]. Red flag symptoms that require further evaluation include weight loss, bloody diarrhea, iron deficiency, and nighttime awakenings.

Similarly, significant family history of IBD, unexplained elevations in the C-reactive protein level and erythrocyte sedimentation rate, or other acute-phase reactants (for example, ferritin and platelets), or low vitamin $B_{12}$ should prompt further investigation for possible CD. Laboratory findings that are useful in $\mathrm{CD}$ are hypoalbuminemia, elevation of the erythrocyte sedimentation rate and C-reactive protein, anemia, or leukocytosis [41-43]. The serologic markers of clinical importance are the anti-Saccharomyces cerevisiae antibodies, which are commonly positive in $\mathrm{CD}$, and antineutrophil cytoplasmic antibody, which is negative for $C D$ [41-43]. These tests are suggestive of $\mathrm{CD}$ but are not meant to be interpreted as diagnostic tests, because positive results could be present in a healthy population The main utility of these antibodies is for differential diagnosis in patients with characteristics of $\mathrm{CD}$ and other diseases, including UC [41-43].

In spite of the widely used diagnostic modalities such as ultrasound, barium x-rays, CT scans, and colonoscopy, a clear diagnosis of $\mathrm{CD}$ may remain obscure. Although no single "gold standard" indicator of this disease has been established, it is indeed possible to make an ideal diagnosis based on the patient's clinical, laboratory, endoscopic, and pathologic data; meanwhile, colonoscopy, capsular endoscopy, and laparoscopy significantly assist clinicians worldwide in elucidating the diagnosis [42]. Both computed tomography enterography (CTE) and magnetic resonance enterography (MRE) allow visualization of the bowel wall, mucosa, and extraluminal complications. CTE and MRE have supplanted small-bowel barium studies as the criterion standard for the diagnosis and assessment of CD [14, 43].

Treatment and prognosis of the disease depend on several factors. The Montreal classification considers age of onset, location, and behavior of the disease, as well as presence of perianal disease, for categorization; many decisions regarding diagnostic approach, treatment, follow-up, and prediction of several outcomes, ranging from response to therapy to long-term prognosis, depend on this classification (Table 1) [44].

Furthermore, for severity scoring, there is an extensive number of validated scores such as the Crohn's Disease Activity Index (CDAI), mainly used in clinical trials because of its complexity, and the Harvey-Bradshaw Index used in the clinical setting owing to its simplicity (Table 2) [45-47].

There is a global resolve among clinicians that the treatment of $\mathrm{CD}$ should depend on disease severity, location of disease, and subtype of disease (that is, inflammatory, stricturing, or penetrating). Attempts are also being made to determine individuals who are at risk for aggressive $\mathrm{CD}$ and who may require earlier and more aggressive therapies. Risk factors for aggressive disease activity include age of diagnosis less than 30 years, extensive anatomic involvement, perianal disease, deep ulcers, prior surgery, and stricturing and/or penetrating disease [10, 48]. One of the biggest challenges associated with $\mathrm{CD}$ is that after 20 years of disease activity, $80 \%$ of patients will require surgery, and approximately $30 \%$ will require surgery within 5 years of diagnosis $[10,41,48]$. Although the goal

Table 1 Montreal classification [10]

\begin{tabular}{ll}
\hline Age at diagnosis & A1: less than 16 years \\
& A2: between 17 and 40 years \\
& A3: over 40 years \\
L1: ileal & L2: colonic \\
Location & L3: ileocolonic \\
L4: isolated upper digestive \\
B1: nonstricturing, nonpenetrating \\
B2: stricturing \\
B3: penetrating \\
P: perianal disease
\end{tabular}


Table 2 Crohn's Disease Activity Index [14]

\begin{tabular}{|c|c|c|}
\hline Variable & Variable description & Multiply Total \\
\hline 1 & $\begin{array}{l}\text { No. of liquid or soft stools (each day } \\
\text { for } 7 \text { days) }\end{array}$ & $\times 2$ \\
\hline 2 & $\begin{array}{l}\text { Abdominal pain, sum of seven daily ratings } \\
\text { ( } 0=\text { none, } 1=\text { mild, } 2=\text { moderate, } 3=\text { severe) }\end{array}$ & $\times 5$ \\
\hline 3 & $\begin{array}{l}\text { Abdominal mass ( } 0=\text { no, } 2=\text { questionable, } \\
5=\text { definite) }\end{array}$ & $\times 10$ \\
\hline 4 & $\begin{array}{l}\text { General well-being, sum of seven daily ratings } \\
(0=\text { generally well, } 1=\text { slightly under par) }\end{array}$ & $\times 7$ \\
\hline 5 & Hematocrit (males 47\%, females $42 \%$ ) & $\times 6$ \\
\hline 6 & $\begin{array}{l}\text { Body weight (1-weight/standard weight) } \\
\text { (add or subtract according to sign) }\end{array}$ & $\times 100$ \\
\hline 7 & $\begin{array}{l}\text { Use of diphenoxylate or loperamide for } \\
\text { diarrhea }(0=\text { no, } 1=\text { yes })\end{array}$ & $\times 30$ \\
\hline 8 & $\begin{array}{l}\text { Number of listed complications (arthritis or } \\
\text { arthralgia, iritis or uveitis, erythema nodosum } \\
\text { or pyoderma gangrenosum or aphthous } \\
\text { stomatitis, anal fissure or fistula or abscess, } \\
\text { other fistula, fever over } 37.8^{\circ} \mathrm{C} \text { ). }\end{array}$ & $\times 20$ \\
\hline
\end{tabular}

Note: Add the eight variables. A total of $<150$ points denotes disease remission and a better outcome; $>450$ points implies severe disease

of medical therapy is to maintain remission without the need for surgery, once strictures and/or fistula complications occur, surgery may be required. Unfortunately, because surgery is not curative for $\mathrm{CD}$, many patients will require multiple surgeries over their lifetime $[10,49]$.

There are a number of different drugs used to treat $\mathrm{CD}$, as highlighted in Table 3. Mesalamine has been evaluated in a number of studies but has not been shown to effectively induce or maintain remission in $\mathrm{CD}$. The perceived benefit of mesalamine is likely related to its safety profile $[10,41]$. Antibiotics are also used in $\mathrm{CD}$, but the evidence supporting their use is also limited [50]. The main role of antibiotics is to treat the suppurative or perianal complications of CD [51].

Immunosuppressants, including AZA, mecaptopurine (MP), and MTX, have been used for many years to treat $\mathrm{CD}$. These drugs are typically used to maintain remission because of their slow onset of action. However, more recent studies question the overall efficacy of AZA/MP as monotherapy and their use in early $C D$ [10, 52-54]. Newer reports have suggested that these drugs can be used in combination with anti-tumor necrosis factor (anti-TNF) drugs to decrease their immunogenicity and also to increase anti-TNF drug concentrations. The mainstay of therapy for CD has been anti-TNF agents.

More recently approved drugs are monoclonal antibodies directed against certain integrins $(\alpha 4$ or $\alpha 4 \beta 7)$ or interleukins (IL-12/IL-23). The first anti-integrin approved for $\mathrm{CD}$ was natalizumab, but this is associated with progressive multifocal leukoencephalopathy (PML), a fatal brain infection $[10,55,56]$. Vedolizumab is a gut-selective anti-integrin that has not been associated with PML and is used mostly to maintain remission in moderate to severe $\mathrm{CD}$ with only modest effectiveness at induction of remission [10, 57]. In contrast, the most recently approved agent, ustekinumab, an IL-12/IL-23 inhibitor, has been shown to be as effective as anti-TNF therapy at inducing and maintaining remission in moderate to severe CD $[10,58]$.

Ultimately, the goal of medical therapy is to induce and maintain a steroid-free clinical remission, prevent complications and surgery, and improve the patient's quality of life $[10,59]$. For typical medication, complications, and monitoring recommendations, see Table 3.

A significant number of patients with $\mathrm{CD}$ can be managed by adopting a conservative approach that includes adequate rest, a nutritious diet, multivitamins, iron, folic acid, antioxidants, and sulfasalazine. Surgical therapy is useful in refractory disease and when complications such as occlusion, abscess, and fistulas develop. Though surgery is required to relieve obstruction, to repair a perforation, to treat an abscess, or to close a fistula, a judicious approach to treating the patient is of utmost importance regarding the decision whether to intervene or to continue with conservative management to avoid life-threatening complications [2]. This evidence confirmed the role of surgical intervention as reported in the index patient.

The outcome of $\mathrm{CD}$ has improved with good medical care. It is serious, but it is not a terminal illness. Mortality in these patients is due to risks of surgery or associated diseases [60]. These patients require very regular follow-up even if they are well, and any new symptom should be given due consideration. The index patient received adjuvant chemotherapy consisting of AZA, MTX, mesalamine, and methylprednisolone. He had complete disease remission.

With respect to prognosis, the literature suggests that almost all patients with $\mathrm{CD}$ have complications; perianal disease is present in approximately $50 \%$. Approximately $40 \%$ will develop active disease within the first 3 years, and disease remains inactive over time in only a small percentage $[14,61]$. The majority will require bowel resections and several surgeries. A review showed that 10 years after diagnosis, $85 \%$ had the same disease location; however, the initial pattern will change after 25 years $[14,61]$. Stenosis or penetrating complications will be found in $60 \%$ of patients in the first 5 years, which will require intensive medical treatment (immunomodulatory and/or biological therapy) [14, 61].

The most recent postoperative abdominal CT scan and colonoscopy revealed disease-free status in the index patient. The index patient is currently receiving a maintenance dose of rectal mesalamine and oral omeprazole treatment. He has been followed every 2 months in the 
Table 3 Medications, monitoring, and adverse events ${ }^{a}[10]$

\begin{tabular}{|c|c|c|c|c|c|}
\hline Group & Drugs & Routes & Efficacy & Recommended testing & Adverse drug reactions \\
\hline 5-Aminosalycilates & $\begin{array}{l}\text { Mesalamine } \\
\text { Balsalazide } \\
\text { Sulfasalazine }\end{array}$ & $\begin{array}{l}\text { Oral } \\
\text { Rectal }\end{array}$ & $\begin{array}{l}\text { Induction and } \\
\text { maintenance }\end{array}$ & $\begin{array}{l}\text { Cr, urinalysis } \\
\text { CBC, LFTs }\end{array}$ & $\begin{array}{l}\text { Headache, nausea, diarrhea } \\
\text { Paradoxical worsening of } \\
\text { symptoms } \\
\text { Interstitial nephritis } \\
\text { Hemolytic anemia, }{ }^{a} \\
\text { leukopenia, }{ }^{a} \text { hepatitis }{ }^{a}\end{array}$ \\
\hline Corticosteroids & $\begin{array}{l}\text { Prednisone } \\
\text { Budesonide } \\
\text { Methylprednisolone }\end{array}$ & $\begin{array}{l}\text { Oral } \\
\text { Rectal } \\
\text { IV }\end{array}$ & Induction only & $\begin{array}{l}\text { Consider checking } \\
\text { hemoglobin A1c and } \\
\text { vitamin D levels } \\
\text { If prolonged steroid } \\
>3 \text { mo: DEXA scan and } \\
\text { ophthalmologic evaluation }\end{array}$ & $\begin{array}{l}\text { Osteopenia/osteoporosis } \\
\text { Avascular necrosis } \\
\text { Serious infection } \\
\text { Weight gain } \\
\text { Insomnia } \\
\text { Mood changes } \\
\text { Delirium } \\
\text { Cataracts } \\
\text { Glaucoma } \\
\text { Skin changes } \\
\text { Delayed wound healing } \\
\text { Adrenal insufficiency }\end{array}$ \\
\hline Thiopurines & $\begin{array}{l}\text { Azathioprine } \\
\text { Mercaptopurine }\end{array}$ & Oral & Maintenance & $\begin{array}{l}\text { TPMT enzyme activity or } \\
\text { genetics before initiation } \\
\text { CBC, LFTs } \\
\text { Skin examinations } \\
\text { Yearly Pap smear in women }\end{array}$ & $\begin{array}{l}\text { Nausea } \\
\text { Vomiting } \\
\text { Transaminitis } \\
\text { Bone marrow suppression } \\
\text { Pancreatitis } \\
\text { Infection } \\
\text { Non-Hodgkin lymphoma } \\
\text { Nonmelanoma skin cancer } \\
\text { Cervical dysplasia }\end{array}$ \\
\hline Methotrexate $^{b}$ & Methotrexate & $\begin{array}{l}\text { SC or IM (limited } \\
\text { efficacy of oral route) }\end{array}$ & $\begin{array}{l}\text { Induction and } \\
\text { maintenance }\end{array}$ & CBC, LFTs & $\begin{array}{l}\text { Infection } \\
\text { Cytopenias } \\
\text { Transaminitis } \\
\text { Cirrhosis } \\
\text { Nausea/vomiting } \\
\text { Flulike symptoms } \\
\text { Oral ulcers } \\
\text { Pulmonary toxicity } \\
\text { Contraindicated in pregnancy }\end{array}$ \\
\hline Anti-TNF & $\begin{array}{l}\text { Infliximab } \\
\text { Adalimumab } \\
\text { Certolizumab pegol }\end{array}$ & $\begin{array}{l}\text { IV } \\
\text { SC }\end{array}$ & $\begin{array}{l}\text { Induction and } \\
\text { maintenance }\end{array}$ & $\begin{array}{l}\text { Latent TB and hepatitis B } \\
\text { before initiation } \\
\text { CBC, LFTs } \\
\text { Skin examinations }\end{array}$ & $\begin{array}{l}\text { Infusion/injection site reaction } \\
\text { Infection } \\
\text { Non-Hodgkin lymphoma (mostly } \\
\text { if combined with a thiopurine) } \\
\text { HSTC-L (if combined with a } \\
\text { thiopurine) } \\
\text { Melanoma } \\
\text { Reactivation of latent TB and } \\
\text { hepatitis B } \\
\text { Drug-induced lupus erythematosus } \\
\text { Demyelinating disease } \\
\text { Psoriasiform and eczema reactions } \\
\text { Worsening of CHF }\end{array}$ \\
\hline $\begin{array}{l}\text { Adhesion molecule } \\
\text { inhibitors }\end{array}$ & $\begin{array}{l}\text { Natalizumab } \\
\text { Vedolizumab }\end{array}$ & IV & $\begin{array}{l}\text { Induction and } \\
\text { maintenance }\end{array}$ & $\begin{array}{l}\text { Natalizumab: JC virus } \\
\text { checking before initiation } \\
\text { and yearly monitoring for } \\
J C \text { virus } \\
\text { Vedolizumab and } \\
\text { natalizumab: } \\
\text { Consider CBC }\end{array}$ & $\begin{array}{l}\text { Infusion reactions } \\
\text { Infection } \\
\text { Nasopharyngeal polyps } \\
\text { PML (natalizumab only with } \\
\text { positive } \\
\text { JC virus }\end{array}$ \\
\hline $\begin{array}{l}\text { IL-12/IL-23 } \\
\text { inhibitors }\end{array}$ & Ustekinumab & $\begin{array}{l}\text { IV } \\
\text { SC }\end{array}$ & $\begin{array}{l}\text { Induction and } \\
\text { maintenance }\end{array}$ & $\begin{array}{l}\text { Latent TB before initiation } \\
\text { Consider CBC, LFTs }\end{array}$ & $\begin{array}{l}\text { Infusion reactions } \\
\text { Skin cancer } \\
\text { Reversible posterior } \\
\text { leukoencephalopathy TB }\end{array}$ \\
\hline
\end{tabular}

Abbreviations: Anti-TNF Anti-tumor necrosis factor, CBC Complete blood cell count, Cr Creatinine, CHF Congestive heart failure, DEXA Dual-energy X-ray absorptiometry, IV Intravenous, IM Intramuscular, SC Subcutaneous, JC John Cunningham, LFT Liver function test, FDA Food and Drug Administration, HSTLC Hepatosplenic T-cell lymphoma, PML Progressive multifocal leukoencephalopathy, Pap Papanicolaou, TB Tuberculosis, TPMT Thiopurine methyltransferase ${ }^{a}$ Sulfasalazine only

${ }^{\mathrm{b}}$ Patients should be given $1 \mathrm{~g}$ of folic acid with the medication to reduce side effects 
surgical outpatient clinic over the last 16 months with a satisfactory clinical outcome.

\section{Conclusions}

$\mathrm{CD}$ is considered by many as a very rare disease in Africa. It is interesting to know that $C D$, which affects mainly young adults, may debut at any age. The symptoms of CD may mimic many other abdominal conditions for which medical attention is required. However, it should be kept in mind as one of the causes of acute abdomen, especially in those patients who have a long history of intestinal pathologies whose treatments greatly differ. Establishing an appropriate treatment in order to avoid short- and long-term complications, which may be life-threatening, depends mainly on distinguishing between other inflammatory disorders of the digestive tract and $\mathrm{CD}$. A histopathologically confirmed diagnosis becomes very necessary also because of the emerging evidence that there is an increased risk of adenocarcinoma in patients with $\mathrm{CD}$.

\section{Acknowledgements}

Not applicable.

\section{Funding}

No record of funding for this case report was declared.

\section{Availability of data and materials}

All data generated or analyzed during this study are included in this published article and can also be accessed via https://doi.org/10.6084/ m9.figshare.7430864.v1.

\section{Disclosures}

The author has no disclosures.

\section{Authors' contributions}

BJA conceived of the study and participated in its design and coordination as well as helped to draft the manuscript. The author also read and approved the final manuscript.

\section{Ethics approval and consent to participate}

Ethical approval is not required for case reports at my institution.

\section{Consent for publication}

Written informed consent was obtained from the patient for publication of this case report and any accompanying images. A copy of the written consent is available for review by the Editor-in-Chief of this journal.

\section{Competing interests}

The author declares that he has no competing interests.

\section{Publisher's Note}

Springer Nature remains neutral with regard to jurisdictional claims in published maps and institutional affiliations.

Received: 14 December 2017 Accepted: 3 January 2019 Published online: 07 March 2019

\section{References}

1. Emory TS, Sobin LH. Idiopathic inflammatory bowel disease. In: lacobuzioDonahue CA, Montgomery EA, editors. Gastrointestinal and liver pathology. 2nd ed. Philadelphia: Elsevier Saunders; 2012. p. 352-366.

2. Dalziel TK. Chronic interstitial enteritis. Br Med J. 1913;2:1068.
3. Lockhart-Mummery HE, Morson BC. Crohn's disease (regional enteritis) of the large intestine and its distinction from ulcerative colitis. Gut. 1960;1:87.

4. Morson BC, Lockhart-Mummery HE. Anal lesions in Crohn's disease. Lancet. 1959;2:1122.

5. Fielding JF, Toye DK, Beton DK, Cooke WT. Crohn's disease of the stomach and duodenum. Gut. 1970;11:1001.

6. Basu MK, Asquith P, Thompson RA, Cooke WT. Proceedings: Oral lesions in patients with Crohn's disease. Gut. 1974;15:346.

7. Huchzermeyer H, Paul F, Seifert E, Frohlich H, Rasmussen CW. Endoscopic results in five patients with Crohn's disease of the esophagus. Endoscopy. 1977;8:75.

8. Rankin GB, Watts HD, Melnyk CS, Kelley ML Jr. National Cooperative Crohn's Disease Study: extraintestinal manifestations of perianal complications. Gastroenterology. 1979;77:914.

9. Greenstein AJ, Sachar DB, Smith H, Janowitz HD, Aufses AH Jr. Patterns of neoplasia in Crohn's disease and ulcerative colitis. Cancer. 1980;46:403.

10. Feuerstein JD, Cheifetz AS. Crohn disease: epidemiology, diagnosis, and management. Mayo Clin Proc. 2017;92(7):1088-103.

11. Molodecky NA, Soon IS, Rabi DM, et al. Increasing incidence and prevalence of the inflammatory bowel diseases with time, based on systematic review. Gastroenterology. 2012;142(1):46-54. e42; quiz e30

12. Ng SC, Bernstein CN, Vatn MH, et al. Epidemiology and Natural History Task Force of the International Organization of Inflammatory Bowel Disease (IOIBD). Geographical variability and environmental risk factors in inflammatory bowel disease. Gut. 2013;62(4):630-49.

13. Loftus EV Jr. Clinical epidemiology of inflammatory bowel dis-ease: incidence, prevalence, and environmental influences. Gastroenterology. 2004;126(6):1504-17.

14. Kúsulas-Delint D, González-Regueiro JA, Rodríguez-Aldama JC, GarcíaMiranda FS, García-Santos RA, et al. Crohn's disease: review and current concepts. Rev Invest Med Sur Mex. 2016;23(1):10-20.

15. Schultz M, Butt A. Is the north to south gradient in inflammatory bowel disease a global phenomenon? Expert Rev Gastroenterol Hepatol. 2012;6(4):445-7.

16. Vind I, Riis L, Jess T, Knudsen E. Increasing incidences of inflammatory bowel disease and decreasing surgery rates in Copenhagen City and County, 2003-2005: a population-based study from the Danish Crohn colitis database. Am J Gastroenterol. 2006;101(6):1274-82

17. Yapp T, Stenson R, Thomas G. Crohn's disease incidence in Cardiff from 1930: an update for 1991-1995. Eur J Gastroenterol Hepatol. 2000;12(8):907-11.

18. Rubin G, Hungin A, Kelly P. Inflammatory bowel disease: epidemiology and management in an English general practice population. Aliment Pharmacol Ther. 2000;14(12):1553-9.

19. Loftus C, Loftus $E_{1}$ Harmsen S. Update on the incidence and prevalence of Crohn's disease and ulcerative colitis in Olmsted County, Minnesota, 19402000. Inflamm Bowel Dis. 2007:13(3):254-61.

20. Bernstein C, Wajda A, Svenson L. The epidemiology of inflammatory bowel disease in Canada: a population-based study. Am J Gastroenterol. 2006; 101(7):1559-68

21. Cosnes J, Gower-Rousseau C, Seksik P. Epidemiology and natural history of inflammatory bowel diseases. Gastroenterology. 2011;140(6):1785-94.

22. Hou J, El-Serag H, Thirumurthi S. Distribution and manifestations of inflammatory bowel disease in Asians, Hispanics, and African Americans: a systematic review. Am J Gastroenterol. 2009;104(8):2100-9.

23. Yamamoto-Furusho J. Clinical epidemiology of ulcerative colitis in Mexico. J Clin Gastroenterol. 2009;43(3):221-4.

24. Cho KJ, Suh YL, Kim CW, Chi JG. Crohn's disease - a case report. J Korean Med Sci. 1987;2(2):133-6.

25. Logan I, Bowlus CL. The geoepidemiology of autoimmune intestinal disease. Autoimmun Rev. 2013;9(5):A372-8.

26. Monstad I, Hovde O, Solberg IC, A Moum B. Clinical course and prognosis in ulcerative colitis: results from population based and observational studies. Annals of Gastroenterology. 2014:27:95-104.

27. Economou M, Zambeli E, Michopoulos S. Incidence and prevalence of Crohn's disease and its etiological influence. Ann Gastroenterol. 2009;22(3): 58-67.

28. Hanauer SB, Sandborn W. Management of Crohn's disease in adults. Am J Gastroenterol. 2001;96(3):635-43.

29. Sathiyasekaran M, Shivbalan S. Crohn's disease. Indian J Pediatr. 2006:73(8): 723-9.

30. Ouyang $\mathrm{Q}$, Tandon $\mathrm{R}$, Goh $\mathrm{KL}$, et al. The emergence of inflammatory bowel disease in the Asian Pacific region. Curr Opin Gastroenterol. 2005;21:408-13. 
31. Wright JP, Froggatt J, O'Keefe EA, et al. The epidemiology of inflammatory bowel disease in Cape Town 1980-1984. S Afr Med J. 1996;70:10-5.

32. Lakatos PL. Recent trends in the epidemiology of inflammatory bowel disease: up or down. World J Gastroenterol. 2006;14:6102-8.

33. Epstein D, Watermeyer $G$, Kirsch R. Review article: the diagnosis and management of Crohn's disease in populations with high-risk rates for tuberculosis. Aliment Pharmacol Ther. 2007;25:1373-88.

34. Steury EM, Templeton AC. Crohn's disease in Africa: a case report and review. Trop Geogr Med. 1980;32(2):172-3.

35. Nguyen GC, Torres EA, Regueiro M, et al. Inflammatory bowel disease characteristics among African-Americans, Hispanics, and non-Hispanic whites: characterization of a large North American cohort. Am J Gastroenterol. 2006;101:1012-23.

36. Mulhall AM, Gholson RD, Eichenberger MR, Galandiuk S. Inflammatory bowel disease and African Americans: a systematic review. Inflamm Bowel Dis. 2008;14(7):960-7

37. Behzadi P, Behzadi E, Ranjbar R. The incidence and prevalence of Crohn's disease in global scale. SOJ Immunol. 2015;3(2):1-6.

38. Platell C, Mackay J, Collopy B, et al. Anal pathology in patients with Crohn's disease. Aust N Z J Surg. 1996;66:5-9.

39. Thompson NP, Wakefield AJ, Pounder RE. Prognosis and prognostic factors in inflammatory bowel disease. Saudi J Gastroentrol. 1995;1(3):129-37.

40. Freeman HJ. Use of the Crohn's disease activity index in clinical trials of biological agents. World J Gastroenterol. 2008;14(26):4127-30.

41. Cheifetz AS. Management of active Crohn disease. JAMA. 2013;309(20): 2150-8.

42. Stange EF, Travis SP, Vermeire S, et al. European evidence based consensus on the diagnosis and management of Crohn's disease: definitions and diagnosis. Gut. 2006:55:1-15.

43. Dambha F, Tanner J, Carroll N. Diagnostic imaging in Crohn's disease: what is the new gold standard? Best Pract Res Clin Gastroenterol. 2014;28(3):421-36.

44. Harbord M, Annese V, Vavricka SR, European Crohn's and Colitis Organization, et al. The first European evidence-based consensus on extraintestinal manifestations in inflammatory bowel disease. J Crohns Colitis. 2016;10(3):239-54

45. Williams $H$, Walker D, Orchard TR. Extra-intestinal manifestations of inflammatory bowel disease. Curr Gastroenterol Rep. 2008;10(6):597-605.

46. Rudwaleit M, Baeten D. Ankylosing spondylitis and bowel disease. Best Pract Res Clin Rheumatol. 2006;20(3):451-71.

47. Wordsworth P. Arthritis and inflammatory bowel disease. Curr Rheumatol Rep. 2000;2(2):87-8.

48. Dassopoulos T, Sultan S, Falck-Ytter YT, Inadomi JM, Hanauer SB. American Gastroenterological Association Institute technical review on the use of thiopurines, methotrexate, and anti-TNF-a-biologic drugs for the induction and maintenance of remission in inflammatory Crohn's disease Gastroenterology. 2013;145(6):1464-78. e5

49. Bernstein CN, Loftus EV Jr, Ng SC, Lakatos PL, Moum B. Epidemiology and Natural History Task Force of the International Organization for the Study of Inflammatory Bowel Disease (IOIBD). Hospitalizations and surgery in Crohn's disease. Gut. 2012;61(4):622-9.

50. Gomollón F, Dignass A, Annese V, et al. ECCO. 3rd European Evidencebased Consensus on the Diagnosis and Management of Crohn's Disease 2016, part 1: Diagnosis and Medical Management. J Crohns Colitis. 2017; 11(1):3-25.

51. Rahimi R, Nikfar S, Rezaie A, Abdollahi M. A meta-analysis of broad-spectrum antibiotic therapy in patients with active Crohn's disease. Clin Ther. 2006; 28(12):1983-8.

52. Cosnes J, Bourrier A, Laharie D, Groupe d'Etude Thérapeutique des Affections Inflammatoires du Tube Digestif (GETAID), et al. Early administration of azathioprine vs conventional management of Crohn's disease: a randomized controlled trial. Gastroenterology. 2013;145(4):758-65. e2; quiz e14-5.

53. Chande N, Patton PH, Tsoulis DJ, Thomas BS, MacDonald JK. Azathioprine or 6-mercaptopurine for maintenance of remission in Crohn's disease. Cochrane Database Syst Rev. 2015:10:CD000067.

54. Panés J, López-Sanromán A, Bermejo F, AZTEC Study Group, et al. Early azathioprine therapy is no more effective than placebo for newly diagnosed Crohn's disease. Gastroenterology. 2013;145(4):766-74. e1

55. Sandborn WJ, Colombel JF, Enns R, International Efficacy of Natalizumab as Active Crohn's Therapy (ENACT-1) Trial Group; Evaluation of Natalizumab as Continuous Therapy (ENACT-2) Trial Group, et al. Natalizumab induction and maintenance therapy for Crohn's disease. N Engl J Med. 2005;353(18):1912-25.
56. Van Assche G, Van Ranst M, Sciot R, et al. Progressive multi-focal leukoencephalopathy after natalizumab therapy for Crohn's disease. N Engl J Med. 2005;353(4):362-8.

57. Sandborn WJ, Feagan BG, Rutgeerts P, GEMINI 2 Study Group, et al. Vedolizumab as induction and maintenance therapy for Crohn's disease. $\mathrm{N}$ Engl J Med. 2013;369(8):711-21.

58. Sandborn WJ, Gasink C, Gao LL, CERTIFI Study Group, et al. Ustekinumab induction and maintenance therapy in refractory Crohn's disease. N Engl J Med. 2012;367(16):1519-28.

59. Panaccione R, Rutgeerts P, Sandborn WJ, Feagan B, Schreiber S, Ghosh S. Review article: treatment algorithms to maximize remission and minimize corticosteroid dependence in patients with inflammatory bowel disease. Aliment Pharmacol Ther. 2008;28(6):674-88.

60. Katsanos KH, Tsianos VE, Maliouki M, et al. Obstruction and pseudoobstruction in inflammatory bowel disease. Ann Gastroenterol. 2010;23(4): 243-56.

61. Louis E, Collard A, Oger AF. Behavior of Crohn's disease according to the Vienna classification: changing pattern over the course of the disease. Gut. 2001:49:777-82
Ready to submit your research? Choose BMC and benefit from:

- fast, convenient online submission

- thorough peer review by experienced researchers in your field

- rapid publication on acceptance

- support for research data, including large and complex data types

- gold Open Access which fosters wider collaboration and increased citations

- maximum visibility for your research: over $100 \mathrm{M}$ website views per year

At BMC, research is always in progress.

Learn more biomedcentral.com/submissions 